\title{
CARBON EMISSION ASSESSMENT FROM DIFFERENT LOGGING ACTIVITIES IN PRODUCTION FOREST OF PAHANG, MALAYSIA
}

\author{
Azian $\mathbf{M}^{1,2, * \text {, Nizam MS }}{ }^{2}$, Samsudin $\mathbf{M}^{1}$, Ismail $\mathbf{P}^{1}$, Nur-Hajar $\mathbf{Z S}^{1}$, Lim KL ${ }^{3} \&$ Yusoff $\mathbf{M}^{3}$ \\ ${ }^{1}$ Forestry and Environment Division, Forest Research Institute Malaysia, 52109 Kepong, Selangor, Malaysia \\ ${ }^{2}$ Institute of Climate Change, Universiti Kebangsaan Malaysia, 43600 UKM, Selangor, Malaysia \\ ${ }^{3}$ Forestry Department Peninsular Malaysia, Jalan Sultan Salahuddin, 50480 Kuala Lumpur, Malaysia \\ *azyan@frim.gov.my
}

Submitted May 2018; accepted January 2019

\begin{abstract}
Logging activities in the forest contribute towards carbon emission into the atmosphere, which impacts global climate. It is anticipated that different logging activities could be a significant factor that contribute to the emission. Hence, a study was conducted to assess logging emission from different logging techniques, viz. the current selective management system (SMS) - reduced impact logging (RIL) prescription, and the improvised of RIL prescription - low impact logging (LIL) using the Rimbaka machine. The study site is a production forest in the Ulu Jelai Forest Reserve, Lipis, Pahang. Surveys were carried out in monitoring plots of RIL and LIL, including carbon emission from logging activities. Assessment of logging emission indicated that the LIL technique emitted much less carbon into the atmosphere compared to RIL technique. Among the emission components, i.e. skid trails, logging roads and logging decks, the amount of emissions were $37 \%$ significantly lower in LIL compared to RIL. In conclusion, improved logging techniques to minimise damages to the residual forest stands are among the mitigation actions taken to reduce carbon emission from timber extraction in the forest. The LIL appears to provide a strategy for managing tropical forest that minimises the potential risks to climate, associated with large changes in carbon emission into the atmosphere.
\end{abstract}

Keywords: Reduced impact logging, low impact logging, forest harvesting, logging emission

\section{INTRODUCTION}

The forestry sector is an important economic sector in Malaysia that generates significant revenue to the country. Apart from that, there is an increasing recognition of its protective roles towards the forests, such as conservation of biodiversity, protection of soil and water resources and stabilising the climate. The forest play an important role in maintaining global temperature by sequestering carbon dioxide from the atmosphere, thus reducing the greenhouse effect that causes climate change. Forest also acts as a storehouse of carbon, not only in the vegetation but also in soils. However, they can also contribute to the release of carbon dioxide into the atmosphere when forests are degraded, cleared and burned (IPCC 2001, 2013). Consequently, mechanisms have been formulated under the UNFCCC such as clean development mechanism (CDM) and reducing emissions for deforestation and degradation (REDD) to reduce emissions. The former achieves this through afforestation and reforestation activities, hence known as CDM-AR, whilst the latter is aimed to include instruments that reduce emissions by reducing deforestation rates and avoiding further forest degradation in developing countries where they are thought to largely occur (IPCC 2001).

Forest logging activities have impacts in increasing carbon emissions that influence changes in climate. Uncontrolled logging and unsupervised selective cutting would result in a small proportion of trees harvested, whilst a large proportion of the forest damaged (Johnson \& Cabarle 1993, Pearson et al. 2014). Heavily damaged residual forests yield little timber and thus are at high risk of conversion to other types of land use. Putz and Pinard (1993) suggested that reducing logging damage is one of the potential activities for carbon sequestration. 
Nevertheless, the effects of reducing logging damage on land-atmosphere gas and energy exchange have not been well quantified (Miller et al. 2011).

In Malaysia, the current logging practice under sustainable forest management (SFM) of reduced impact logging (RIL) is anticipated as one of the logging practices that could minimise damages to forest stands, thus reducing carbon emission into the atmosphere. The RIL also involves harvesting operations which are carefully controlled and intensively planned for their implementation to minimise environmental impacts on forest stands and soils. Moreover, improvised logging techniques, called low impact logging (LIL), could minimise the disruption of tropical forest carbon and water cycles, thereby reducing the amount of carbon emitted into the atmosphere. The LIL involves harvesting activities, in general, which are environmental friendly. It concerns towards large, strong trees and are unharmed during forest clearing. The LIL is considered as a part of RIL, nevertheless, for easier comparison between the two logging techniques, in this study, the use of Rimbaka harvesting machine is called as LIL technique, while the combination of crawler tractor and winch lorry is called RIL technique. The use of Rimbaka harvesting machine as a method of LIL has been introduced in several forest logging activities in peat swamp forests (Ismail 2009, Zulkifli 2005). The Rimbaka is a modified tractor machine with an extended boom and powerful winching system, operating the same way as a mobile highlead yarding system (Chong \& Latifi 2003).

This study explored the potential of carbon retention in managed forests by reducing avoidable logging damage. The carbon retention was assessed by monitoring logging emission from different logging activities of conventional practices under RIL and LIL of Rimbaka machine. It is anticipated that by improving logging practices, fewer trees are felled or damaged during logging and more carbon remains in the forest living trees.

\section{MATERIALS AND METHODS}

\section{Study area}

The Ulu Jelai Forest Reserve (UJRF) located in the forest district of Lipis, Pahang, Malaysia was chosen as the study area. The forest is categorised as an undisturbed production forest and all the compartments chosen will undergo logging for the first time (Figure 1). The study site is located at longitude $101^{\circ} 26^{\prime}-101^{\circ} 58^{\prime} \mathrm{E}$ and latitude $4^{\circ} 4^{\prime}-4^{\circ} 45^{\prime} \mathrm{N}$. The elevation is about 60-800 $\mathrm{m}$ above sea level with a maximum slope of $41^{\circ}$. The area has an annual precipitation of between 1500-2000 $\mathrm{mm}$ and temperature range of $15.5-24.2{ }^{\circ} \mathrm{C}$.

Two study sites were selected in UJFR. The first site was compartment 18A \& 29B where logging activities were conducted under the current prescription of SMS-RIL using the combination of crawler tractor and winch lorry. The second site was compartment 437A \& 447A where logging activities were under the improvised prescription of SMS-LIL using Rimbaka machine. The locations of the study sites are shown in Figure 1 and 2.

\section{Estimation of logging emission}

Logging emission was estimated based on IPCC gain-loss approach that focuses on direct losses in live biomass caused by felled trees, incidental damage to other trees caused by the felling and related logging infrastructure, and the gains from regrowth in and around the gaps caused by felled and damaged trees and infrastructure (Pearson et al. 2014). In this sense, it is more appropriate to estimate the change in live and dead biomass pools due to logging impacts directly in the harvested areas, as opposed to estimating the difference in carbon stocks of the pre- and post-logged forest. The detailed procedures to estimate logging emissions were described by Walker et al. (2014) for lowering emissions in Asia's forests (LEAF), of which two standard operating procedures (SOPs) were referred: i) SOP carbon stock damage in harvesting gaps due to tree felling, and ii) SOP area damaged due to log extraction.

The logging emission survey was carried out two weeks after completion of logging operations in the designated compartments. For estimating carbon stock damage in logging gaps due to tree felling, the logging gap was initially identified and number of felled timber trees were determined and located within the specific logging gap. The felled timber trees and killed and/or damaged trees caused by tree felling were measured as one logging gap plot. Since most of the logs had 


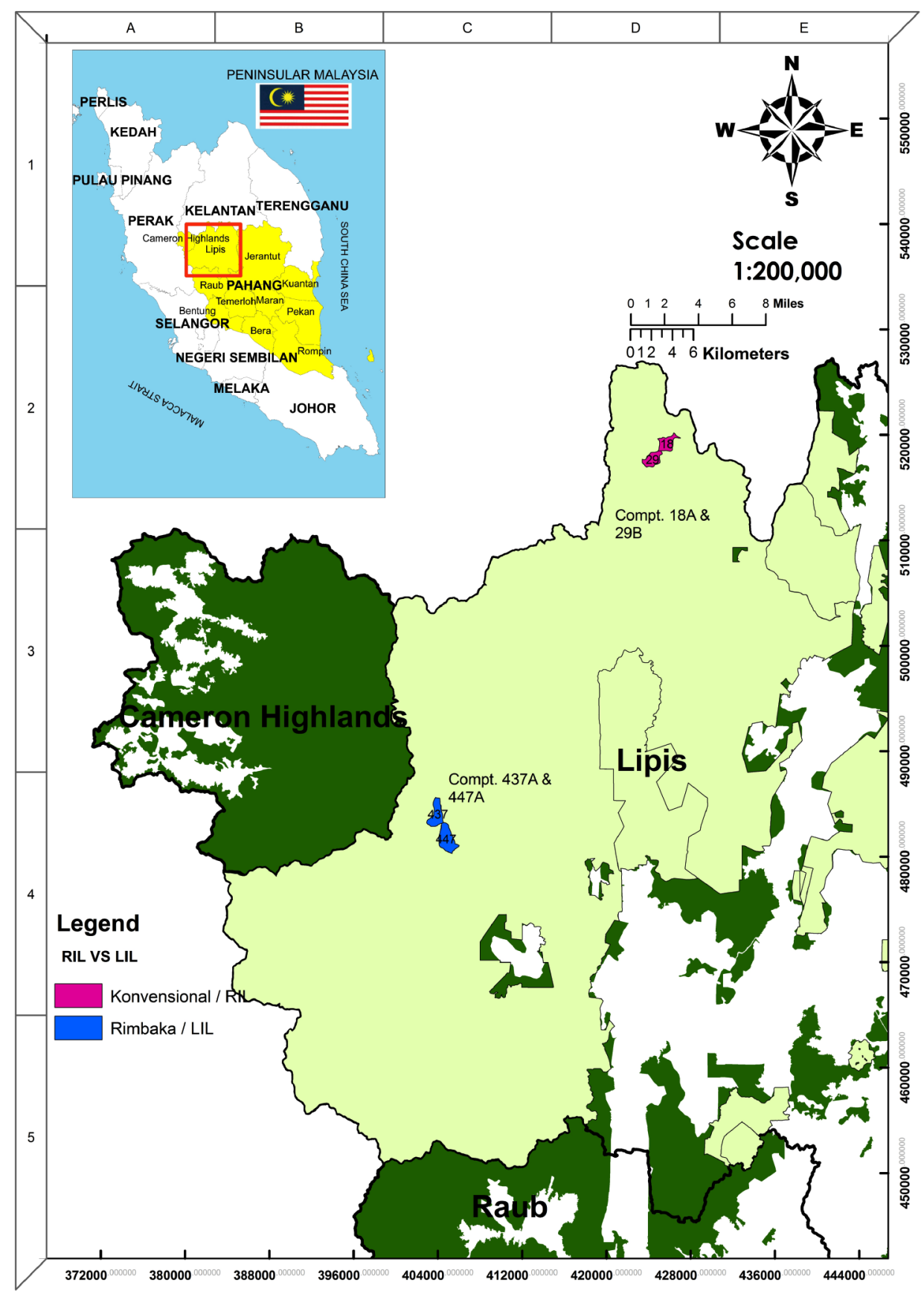

Figure 1 Locations of reduced impact logging (RIL) and low impact logging (LIL) in Ulu Jelai Forest Reserve (UJFR), Lipis, Pahang

been removed prior to data collection, the stump and crown of each felled tree were located and verified by determining the angle of the tree fall, species and reasonable distance from the stump. In the case where log was still present and the stump was tall enough, the diameter was measured directly on both log and stump. For those logs that had been extracted where the actual DBH could not be measured, the
DBH was conservatively estimated to be equal to the diameter at the top cut. Figure $3 \mathrm{a} \& \mathrm{~b}$ shows measurement of stump and top cut in the field.

Estimation of carbon stock for the damaged area due to log extraction was conducted on skid trails, logging roads and logging decks. The lengths and widths of skid trails and logging roads were measured to estimate carbon damage by measuring biomass of trees killed during skid 

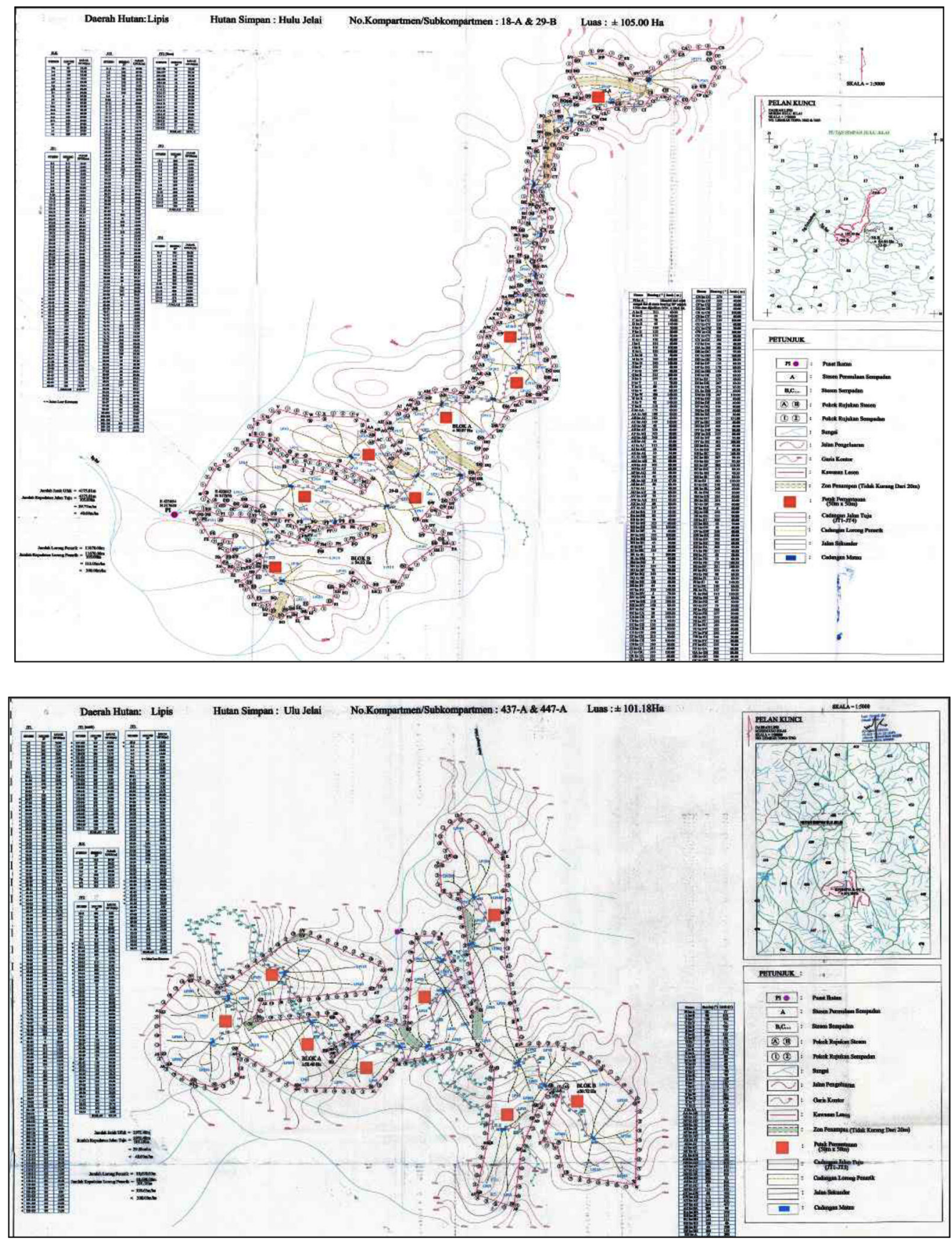

Figure 2 Detail locations of reduced impact logging (RIL) and low impact logging (LIL) in compartment $18 \mathrm{~A} \& 29 \mathrm{~B}$ and compartment 437A \& 447A

trails and creation of logging roads (Figure 4 and 5). However, in the LIL/Rimbaka logging area, no skid trails were established, hence estimation of carbon stock was not conducted for this component. Subsequently, lengths and widths of logging decks were also measured to determine areas of logging decks. Calculation template included methods and rules prepared by Winrock International Version 2014, to estimate carbon stock damage from all measured components (Figure 6).

\section{Calculation of total emission factor (TEF)}

Based on the prepared template, the total emission factor was estimated as the sum of three factors: (i) emissions relative to extracted volume, (ii) damaged biomass in the process of harvesting and (iii) damaged biomass resulting from infrastructure necessary for logging:

$$
\mathrm{TEF}=(\mathrm{ELE}+\mathrm{LDF}+\mathrm{LIF}),
$$



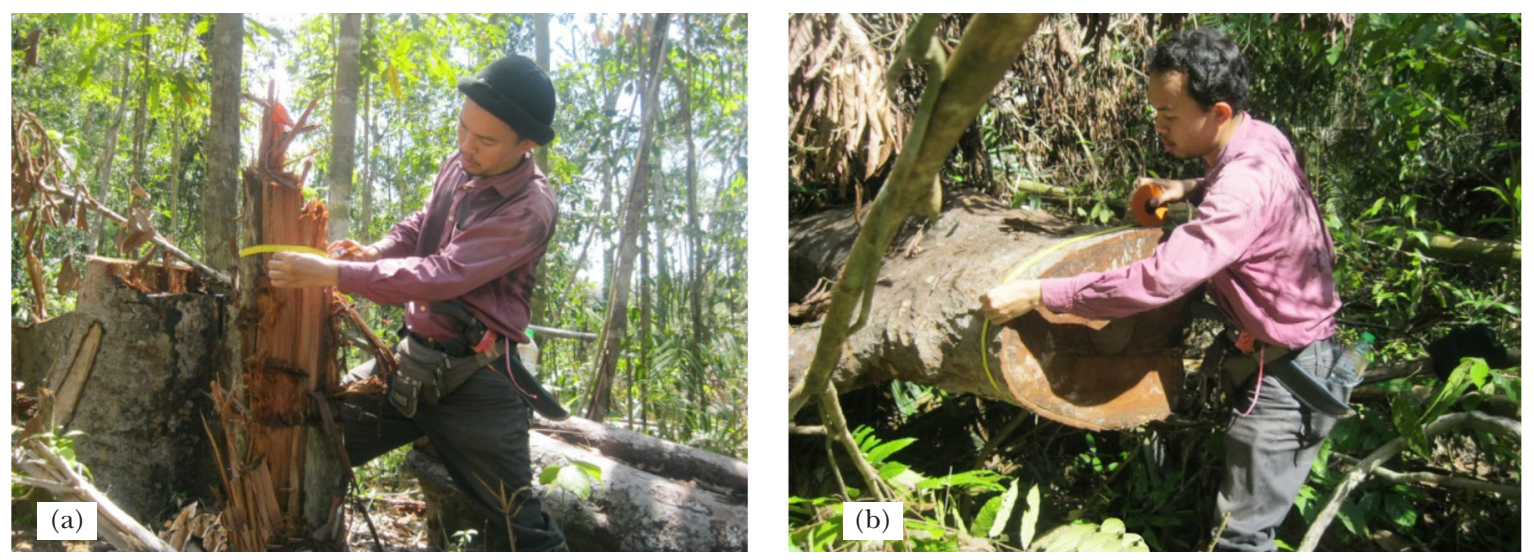

Figure 3 Measurement of (a) tree stump and (b) top cut

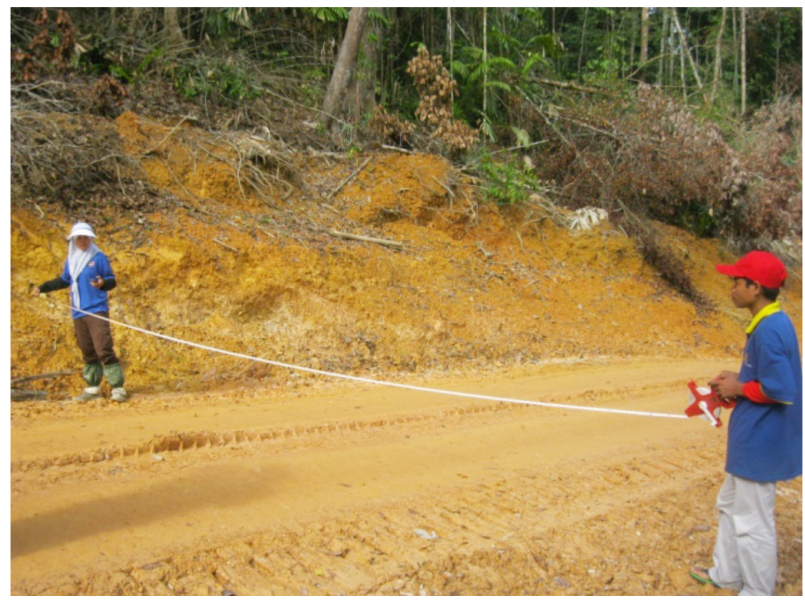

Figure 4 Measurement of logging roads

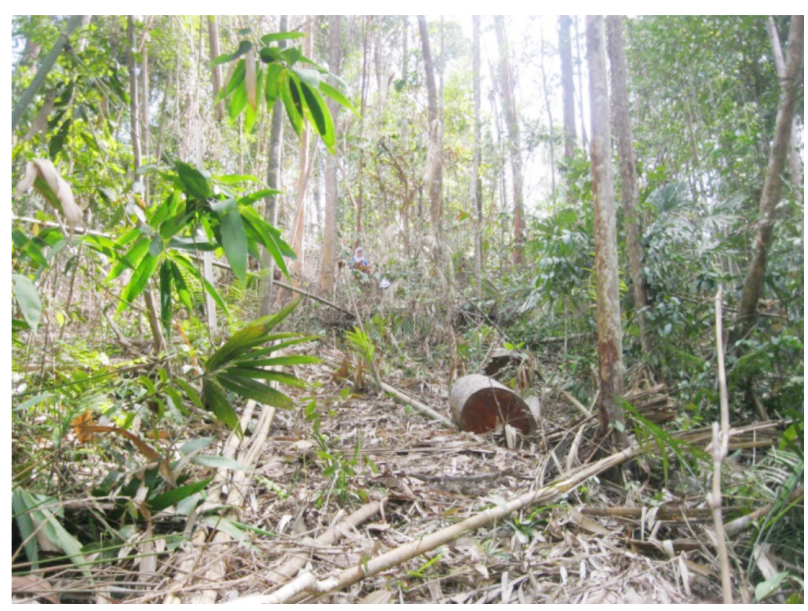

Figure 5 Skid trail at study site of LIL prescription for first time logging

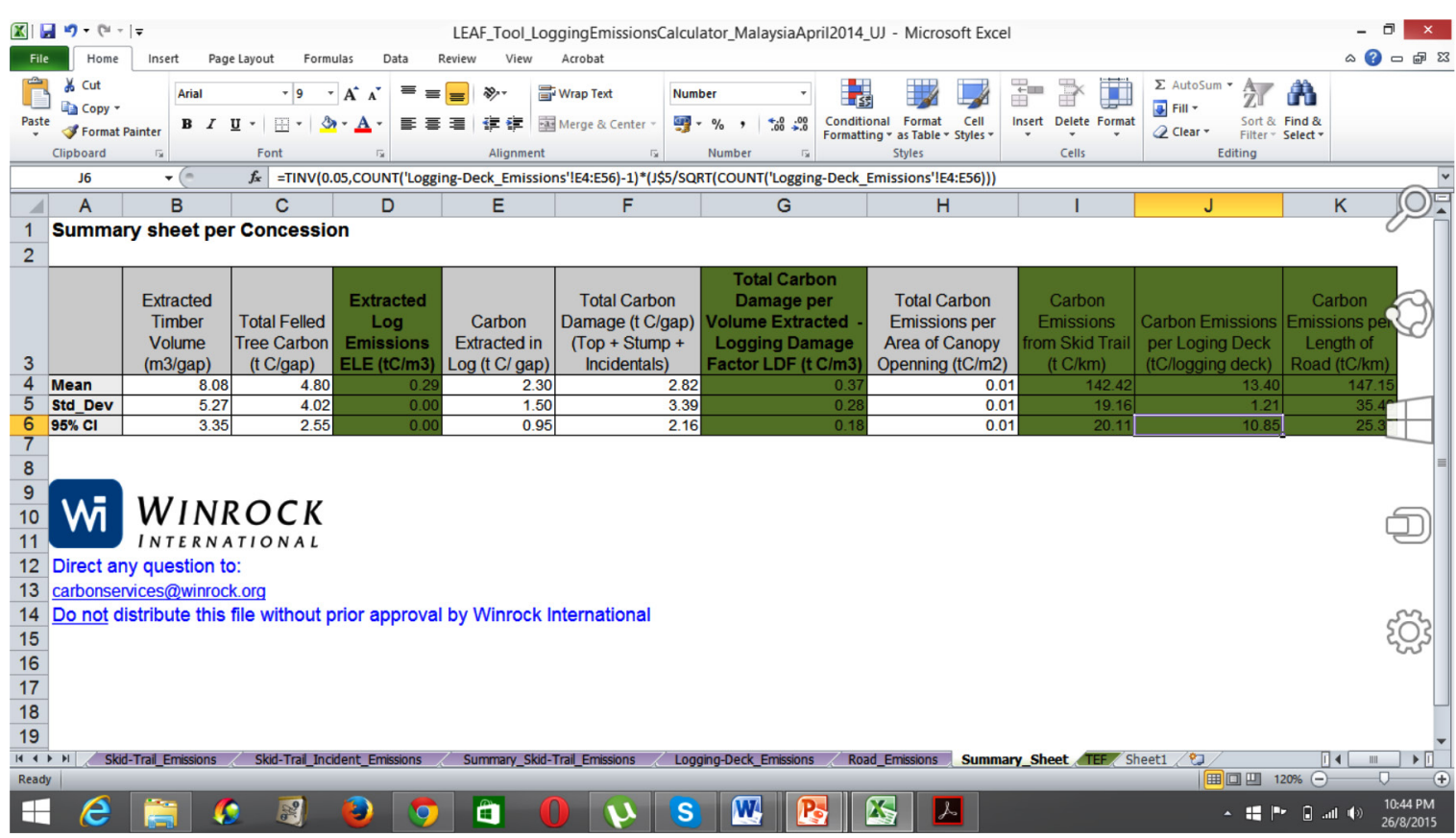

Figure 6 Interface example of calculation template prepared by Winrock International Version 2014 to estimate carbon stock damage from all measured components 
where TEF is the total emission factor resulting from timber harvest of tonne carbon for every cubic metre (tonne $\mathrm{m}^{-3} \mathrm{C}$ ), ELE is the extracted log emissions (tonne $\mathrm{m}^{-3} \mathrm{C}$ extracted), LDF is the logging damage factor - dead biomass carbon left behind in gap from felled tree and incidental damage (tonne $\mathrm{m}^{-3} \mathrm{C}$ extracted) and LIF is the logging infrastructure factor - dead biomass carbon caused by construction of infrastructure (tonne $\mathrm{m}^{-3} \mathrm{C}$ ) (Pearson et al. 2014).

Extracted log emissions (ELE) are equal to the emissions resulting from conversion of the log to wood products and the subsequent emissions from retired wood products. Emissions can be estimated to occur fully at time of harvest (committed emissions) or they can be estimated for specific years after harvest to account for emissions that happen over a prolonged period (IPCC 2006). To simplify the carbon accounting process, IPCC Tier 1 was adopted with the assumption that all extracted carbon is emitted at the time of the event (Pearson et al. 2014).

The logging damage factor (LDF) reflects the emissions that occur at the location (gap) where the specific tree(s) are felled, caused by the decomposition of dead wood produced as a result of tree(s) felling. This represents the carbon in the aboveground and belowground biomass of the stump and top of the timber tree felled and left as dead wood in the forest including trees incidentally killed or severely damaged (i.e. uprooted or snapped) and large branches broken off from surviving trees during tree felling.
Logging infrastructure emissions factor (LIF) includes emissions resulting from the creation of logging roads, skid trails and logging decks. Under some accounting schemes, roads and decks will be counted as deforestation because they will show up in moderate resolution imagery analysis (e.g. Landsat), and their emissions can be addressed through stock difference approach (e.g. area of change multiplied by emission factor derived from $\mathrm{C}$ stocks of unlogged forest). However, the direct correlation with logging makes it logical to include all sources of emissions under timber management.

\section{RESULTS AND DISCUSSIONS}

Carbon emission from logging activity was calculated and results are summarised in Table 1. The logging emission was mainly calculated from the construction of skid trails, logging roads and logging decks. Comparing logging emissions between RIL and LIL/Rimbaka, it was clear that LIL/Rimbaka emitted low carbon during timber harvesting compared to RIL. For skid trail component, the RIL logging area contributed total carbon emission of 142.42 tonne $\mathrm{km}^{-1} \mathrm{C}$, of which included emissions from skid trails and incidental damages of trees that occur along the skid trails; the former was estimated to emit 86.06 tonne $\mathrm{km}^{-1} \mathrm{C}$ whilst the latter emitted 54.36 tonne $\mathrm{km}^{-1} \mathrm{C}$. Nevertheless, the LIL/Rimbaka operation contributed zero carbon emission from the skid trail, since no skid trails were

Table 1 Summary of logging emission of various components in both logging areas of RIL and LIL/Rimbaka, at Ulu Jelai FR, Pahang

\begin{tabular}{|c|c|c|c|c|}
\hline & \multicolumn{2}{|c|}{ RIL } & \multicolumn{2}{|c|}{ LIL/Rimbaka } \\
\hline & Mean & SE & Mean & SE \\
\hline Extracted timber volume $\left(\mathrm{m}^{3} \mathrm{gap}^{-1}\right)$ & 8.08 & 3.52 & 26.18 & 5.97 \\
\hline Total felled tree carbon $\left(\mathrm{tC} \mathrm{gap}^{-1}\right)$ & 4.80 & 1.38 & 10.10 & 1.91 \\
\hline Extracted log emissions (ELE) $\left(\mathrm{tC} \mathrm{m}^{-3}\right)$ & 0.29 & 0.00 & 0.29 & 0.00 \\
\hline Carbon extracted in $\log \left(\mathrm{tC} \mathrm{gap}^{-1}\right)$ & 2.30 & 0.43 & 7.46 & 1.70 \\
\hline $\begin{array}{l}\text { Total carbon damage }\left(\mathrm{tC} \text { gap }^{-1}\right) \\
(\text { top }+ \text { stump }+ \text { incidentals })\end{array}$ & 2.82 & 0.98 & 4.75 & 2.82 \\
\hline $\begin{array}{l}\text { Total carbon damage per volume extracted - logging damage factor } \\
(\mathrm{LDF})\left(\mathrm{tC} \mathrm{m}^{-3}\right)\end{array}$ & 0.37 & 0.08 & 0.36 & 0.13 \\
\hline Total carbon emissions per area of canopy opening $\left(\mathrm{tC} \mathrm{m}^{-2}\right)$ & 0.01 & 0.01 & 0.02 & 0.01 \\
\hline Carbon emissions from skid trail $\left(\mathrm{tc} \mathrm{km}{ }^{-1}\right)$ & 142.42 & 7.14 & 0.00 & 0.00 \\
\hline Carbon emissions per logging deck (tC/logging deck) & 13.40 & 0.86 & 3.25 & 0.73 \\
\hline Carbon emissions per length of road $\left(\mathrm{tC} \mathrm{km}^{-1}\right)$ & 147.15 & 11.22 & 122.42 & 6.34 \\
\hline
\end{tabular}

$\mathrm{SE}=$ standard error 
constructed during timber extracting using Rimbaka machine. The Rimbaka machine used cables to pull the log to a temporary log yard, thus no skid trails were built and they were almost invisible. As for logging roads, the RIL activities emitted an estimation of 147.15 tonne $\mathrm{km}^{-1}$ C, whereas the LIL/Rimbaka area showed less amount of emission of 122.42 tonne $\mathrm{km}^{-1} \mathrm{C}$. This is due to the length of the forest road in RIL area $(9 \mathrm{~km})$ which was longer than the LIL area $(6 \mathrm{~km})$. Subsequently, emission from the logging decks in RIL area was estimated to emit 13.40 tonne of $\mathrm{C}$ per logging deck. However, less amount of emission was observed in the LIL/Rimbaka area with estimated emission of 3.25 tonne of C per logging deck. High amount of emission in the RIL was due to large areas of small logging decks (0.76 ha) compared to LIL/Rimbaka area $(0.60 \mathrm{ha})$. Based on these components, the values of ELE and LDF were 0.29 tonne $\mathrm{m}^{-3} \mathrm{C}$ and 0.37 tonne $\mathrm{m}^{-3} \mathrm{C}$ respectively, in RIL area, whilst the ELE and LDF in LIL/Rimbaka area were 0.29 tonne $\mathrm{m}^{-3} \mathrm{C}$ and 0.36 tonne $\mathrm{m}^{-3} \mathrm{C}$, respectively.

Subsequent analysis was conducted to calculate the overall emission from both logging areas based on total timber volume extracted and total road length constructed (Table 2). It was apparent that timber volume extracted from RIL area was far higher compared to LIL area; the former displayed total volume of 5698 $\mathrm{m}^{3}$ whilst the latter was $3463 \mathrm{~m}^{3}$. These values reflected total carbon emitted volume per hectare of 54.27 tonne $\mathrm{m}^{-3} \mathrm{C}$ and 34.23 tonne $\mathrm{m}^{-3}$ $\mathrm{G}$ in RIL and LIL areas, respectively. The total emission factor (TEF) calculated for RIL and LIL/Rimbaka areas were 1.45 tonne $\mathrm{m}^{-3} \mathrm{C}$ and
0.85 tonne $\mathrm{m}^{-3} \mathrm{C}$, respectively. The TEF values gained from these results were similar to other countries such as Belize, Bolivia, Brazil, Guyana, Indonesia and Congo, with values ranging from 0.99 tonne $\mathrm{m}^{-3} \mathrm{C}$ to 2.33 tonne $\mathrm{m}^{-3} \mathrm{C}$ (Pearson et al. 2014). The value of TEF gained was due to damage made by the surrounding trees as well as the infrastructure of the logging area, rather than logs extracted. Using multiplication of TEF values and total harvested volume per hectare, total carbon emission per hectare was calculated for RIL and LIL as 78.69 tonne $\mathrm{ha}^{-1} \mathrm{C}$ and 29.09 tonne ha ${ }^{-1} \mathrm{C}$, respectively.

The results gathered from this study clearly indicated that different harvesting techniques in logging industry could contribute to different amount of carbon emission into the atmosphere. Logging activities are typically very destructive practices with regards to the preservation of ecosystem carbon stocks. It has been reported that the carbon density of the forest declined after logging. Lasco et al. (2005) reported the decline of carbon density by $50 \%$ after logging in a Philippines mature forest. In addition, Putz and Pinard (1993) observed that an extraction of $8-15$ trees $\left(80 \mathrm{~m}^{3}\right.$; ca. 22 tonne $\left.\mathrm{ha}^{-1} \mathrm{C}\right)$ in Malaysian forest damaged as many as $50 \%$ of the remaining trees. Thus, the LIL by using Rimbaka machine clearly reduced damages to the residual forest stands, thus reducing carbon emitted from tree damages.

\section{CONCLUSION}

Knowledge of the relative magnitude of emission source from different logging techniques

Table 2 Overall emission from both logging areas based on total timber volume extracted and total road length constructed

\begin{tabular}{lcc}
\hline & RIL & LIL/Rimbaka \\
\hline Total logged volume $\left(\mathrm{m}^{3}\right)$ & 5698 & 3463 \\
Total length of skid trail $(\mathrm{km})$ & 11.87 & 0 \\
Total length of roads $(\mathrm{km})$ & 9 & 6 \\
Total number of logging decks & 1 & 1 \\
Total logging area $(\mathrm{ha})$ & 105.0 & 101.18 \\
Total volume per hectare $\left(\mathrm{m}^{3} / \mathrm{ha}\right)$ & 54.3 & 34.2 \\
Total emission factor $(\mathrm{TEF})\left(\mathrm{tC} \mathrm{m}^{-3}\right)$ & 1.18 & 0.86 \\
Total carbon emissions $(\mathrm{tC})$ & 6747 & 2984 \\
Total carbon emissions per hectare $\left(\mathrm{tC} \mathrm{ha}^{-1}\right)$ & 64.1 & 29.4 \\
\hline
\end{tabular}


provides the information needed to design possible actions for reducing emissions by improving logging practices. Emissions from logging damage (LDF) are generally the largest source of emission for most logging areas, followed by infrastructure damage which includes construction of logging roads and logging decks. Efforts to reduce the emission sources could include extracting more timber per felled tree and reducing waste, improving directional felling and thus reducing incidental damage to surrounding trees, planning infrastructure more effectively in areas with greater concentration of timber trees and use of cable extraction of timber instead of creating skid trails up to the stump of the felled trees, of which the Rimbaka machine displayed this proposed technique. The ability to reduce emissions through changes in logging practices contributes to the efforts to implement sustainable forest management under REDD+.

\section{Funding}

This work was supported by the ITTO REDDES Project and $10^{\text {th }}$ Malaysian Development Plan (RMK-10) grants.

\section{ACKNOWLEDGEMENTS}

The authors would like to express their sincere gratitude to FRIM-ITTO REDDES Project for the opportunity to collaborate in a significant component of the project. The authors are indebted, particularly to the dedicated staff of Climate Change Program in FRIM, for their continued support in collecting information throughout the the project; Noraishah S, Nazarudin R, Shahrizal S, Ab-Razal AL and AbuHusin H. Special gratitude goes to Universiti Kebangsaan Malaysia (UKM) for providing technical support, namely, Ahmad-Fitri Z, NikNorafida NA and Nur-Syamimi SM. The Forestry Department Peninsular Malaysia, the Pahang State Forestry Department and the District Forest Office of Lipis are also acknowledged for their assistance rendered at Ulu Jelai Forest Reserve, Lipis.

\section{REFERENCES}

Chong WC \& Latifi A. 2003. The application of reduced impact logging (RIL) in peat swamp timber harvesting: a Rimbaka's experience. Paper presented at the International Conference of Forestry and Forest Products Research (CFFPR 2001): Tropical Forestry Research in the New Millennium - Meeting Demands and Challenges. Forest Research Institute Malaysia (FRIM), Kepong.

IPCC. 2001. Summary for policymakers - land use, landuse change and forestry. http://www.ipcc.ch/pdf/ special-reports/spm/srl-en.pdf

IPCC. 2013. Summary for policymakers. Pp 3-32 in Thomas and Qin (ed). Climate Change 2013: The Physical Science Basis. Working Group I-V Assessment Report of the Intergovernmental Panel on Climate Change. Cambridge University Press, Cambridge.

IsMAIL P. 2009. Phenology, habitat specialization and reduced impact logging of Gonystylus Bancanus (Miq.) Kurz in Pekan Forest Reserve, Pahang. PhD thesis. Universiti Kebangsaan Malaysia (UKM), Bangi.

Johnson NC \& Cabarle B. 1993. Surviving the Cut: Natural Forest Management in the Humid Tropics. World Resources Institute, Washington

Lasco RD, Pulhin FB \& Banaticla MRN. 2005. Potential Carbon Sequestration Projects in the Philippines. Environmental Forestry Program. University of the Philippines Los Banos, College of Forestry and Natural Resources, College, Laguna.

Miller SD, Goulden ML, Hutyra LR, et Al. 2011. Reduced impact logging minimally alters tropical rainforest carbon and energy exchange. Proceedings of the National Academy of Sciences of the United States of America 108: 5 .

Pearson TRH, Brown S \& Casarim FM. 2014. Carbon emissions from tropical forest degradation caused by logging. Environmental Research Letters 9: 034017.

Putz FE \& PInARd MA. 1993. Reduced-impact logging as a carbon-offset method. Conservation Biology 7: 3.

Walker SM, Pearson TR, Casarim FM et al. 2014. Standard Operating Procedures for Terrestrial Carbon Measurement. Winrock International, Virginia.

ZuLKIFLI A. 2005. Logging damage in harvesting systems in peat swamp forests. Paper presented at the Workshop on Developing Sustainable Management Guidelines for Peat Swamp Forest, Kuantan. 